\title{
Use of Social Media as an Effective Marketing Tool for Fashion Startups in Saudi Arabia
}

\author{
Noran Trad, Maha Abdullah Al Dabbagh \\ King Abdulaziz University, Jeddah, KSA \\ Email: noran.trad@gmail.com, Maldabag@kau.edu.sa
}

How to cite this paper: Trad, N., \& $\mathrm{Al}$ Dabbagh, M. A. (2020). Use of Social Media as an Effective Marketing Tool for Fashion Startups in Saudi Arabia. Open Journal of Social Sciences, 8, 319-332. https://doi.org/10.4236/jss.2020.811029

Received: October 27, 2020

Accepted: November 24, 2020

Published: November 27, 2020

Copyright $\odot 2020$ by author(s) and Scientific Research Publishing Inc. This work is licensed under the Creative Commons Attribution International License (CC BY 4.0).

http://creativecommons.org/licenses/by/4.0/

(c) (i) Open Access

\begin{abstract}
In Saudi Arabia, the social media has encouraged and facilitated promotion and creation of various business, resulting in the development of many startup fashion businesses on platforms such as Instagram and Facebook. However, current literature does not offer an in-depth analysis to this topic and the potential of this digital market. Therefore, the following research covers the topic of effect of social media fashion marketing for startup fashion brands in Saudi Arabia. Utilizing many scientific articles on social media marketing and general literature on fashion marketing, this research aims to improve the understanding of the benefits of use of social media as an effective marketing tool for fashion startups by means of examining existing knowledge on social media marketing, and explains how fashion startups can use social media to benefit their businesses. It tries to familiarize targeted audience, including potential fashion startup entrepreneurs, with many concepts and strategies related to social media marketing such as content marketing, consumer engagement, impact of influencers, user generated content, consumer purchasing behavior of fashion brands.
\end{abstract}

\section{Keywords}

Social Media Marketing, Influencers, Consumer Purchasing Behavior, Fashion Startup, Saudi Arabia

\section{Introduction}

Billions of people around the world use the social media as it has become one of the defining technologies of our time. As of March 31, 2019, Facebook, for instance, was reported to have 2.38 billion monthly users and 1.56 billion daily active users (Facebook, 2019). At the global level, the total number of social media users is estimated to increase by 3.29 billion users in 2022, which will be 
$42.3 \%$ of the world's population (eMarketer, 2018). It is not surprising then, given the huge volume of audience who are spending many hours a day using social media, that marketers have resorted to the social media as a marketing platform.

Nowadays, social media has become a powerful tool for advertising. The internet, social media, mobile apps, and other digital devices have become part of daily lives for majority of population all over the world. Recent statistics have indicated that the most popular social network is Facebook, with over 2.7 billion monthly active users as of the second quarter of 2020 (Clement, 2020). Instagram, meanwhile, has become the most popular site for sharing photos with over 500 million monthly active users. The total number of monthly active Instagram users has reached 1 billion (Clement, 2019).

Social media provide a popular place for communication and sharing content between people (Buhalis \& Foerste, 2015). Using the social network, consumers are able to communicate more effectively. For instance, via a social network, customers can look for others' experience with products (Berthon et al., 2012; Pitt et al., 2002). Moreover, social media create a new method for companies and brands to search for new methods of obtaining and attracting the customers (Gallaugher \& Ransbotham, 2010). The relationship between consumers and social media has been dramatically fostered as the social media became the place for people to share their personal stories about purchase process (Adams, 2011). Social media provides access to the customers to share their experiences and recommend certain products, so, the purchasing decisions change after using that source of information (Chen et al., 2011). However, nowadays, the increasing speed of new trends and the demand for change is getting faster and this has encouraged the majority, if not all fashion brands, to adopt the social media as a marketing channel. Thus, social media has become the shopping hub for both consumers and fashion brands all over the world.

Consumers' instant use of social media platforms as entertainment has resulted in a high demand of fashion brands on social media and this constant engagement acts as an insurance for brands that higher chances for consumers are likely to view their products. In addition, fashion brands can consider social media as a market research tool because it gives them a deeper understanding of the market situation and help them gain knowledge of the consumers and their requirements (Posner, 2015).

Using social media as a tool to facilitate and create business is a new and growing method of entrepreneurship, with various social media-based platforms allowing brands to launch with minimum capital outlay, display their products in an easily accessible format and interact with their potential customers. In Saudi Arabia, however, the benefits of social media are a little bit different. With the various cultural norms and mindsets, social media is considered not only as a marketing tool for existing brands but also as a motivating factor for new businesses to launch (Al-Maghrabi \& Dennis, 2011). 
Therefore, in this paper, the researcher seeks to improve the understanding of the benefits of use of social media as an effective marketing tool for fashion startups by means of examining existing knowledge on social media marketing, and tries to demonstrate how fashion startups can use social media to benefit their businesses. Utilizing many scientific articles on social media marketing and general literature on fashion marketing, the researcher tries to explain and clarify how the social media can be used as an effective marketing tool for fashion. The researcher also highlighted many common concept and strategies related to social media marketing including content marketing, consumer engagement, impact of influencers, user generated content, consumer purchasing behavior of fashion brands.

\section{Research Methodology}

Researches can be carried out using different approaches, depending on the nature and aim the research. Main sources of information have been utilized in producing this paper, including many scientific articles on social media marketing and general literature on fashion marketing. These sources have provided sufficient information to conduct an analysis of benefits fashion startups can generate when adopting the social media as a marketing tool. The paper applies the qualitative approach as a method to realize the study, as it analyses the work of many authors to reach the objectives of the research.

\section{Literature Review}

Social media has enabled average consumers to have much more interaction with fashion designers. Social media is a platform that reaches across the globe and has a great impact on how consumers interact with the fashion industry. Because of its popularity, social media has become an important tool of marketing due to its ease of access for both consumers and brands. It is an element of Web 2.0 whereby content is no longer created and published by individuals, rather continuously modified by all users in a collaborative and participatory fashion (Montecchi \& Nobbs, 2017). Therefore, the growth of social networks has created a new generation of empowered consumers who are able to exchange information and influence the behaviors and attitudes of other consumers (Montecchi \& Nobbs, 2017).

The following literature highlights the importance of social media as marketing tool and examines key strategies and concepts that potential fashion startups can utilize in the digital market arena. Relevant strategies and concepts such as content marketing, consumer engagement, user generated content and impact of influencers have been discussed in details in order to attract potential fashion startups to the usefulness of such strategies in promoting their online businesses and familiarize them with current trends in digital marketing.

Effect of social media as a marketing tool for fashions 
The power of social media on fashion industry is undeniable. Social media for the fashion industry refers to the social networking websites and other online platforms that enable the fashion industry to reach their potential customers using the latest social networking tool. The fashion Industry has become more accessible to the public by virtue of the social media which has grown dramatically in the recent years.

The era of digitalization and the development of social networks are radically changing traditional communication paradigms, influencing the way companies communicate and, more importantly, interact with customers (Essamri, McKechnie, \& Winklhofer, 2019; Gielens \& Steenkamp, 2019). Social media marketing is a category of digital marketing that monitors and facilitates customer-to-customer interaction and participation throughout the web to encourage positive engagement with a company and its brands (Chaffey \& Ellis-Chadwick, 2016).

Over the last decade social media has become an effective marketing tool, it has not only created a new dimension of marketing but has also provided many opportunities to the marketers to create brand awareness among consumers.

Social media is a compilation of digital platforms and channels that are used by people to share information, profiles, assumptions, observations, perspicacity, apprehension and media itself, it facilitates communication and interactions between different groups of people from all across the world (Hill \& Moran, 2011).

When we talk about social media for the fashion industry it refers to the social networking websites and other online platforms that enable the fashion industry to connect with their customers using the latest social networking technology. The fashion industry is using social media to study trends and anticipate fashion behaviors. It is embracing social media which has enabled it to emerge in the forefront as a phenomenon.

The development of social networking website such as Facebook and Instagram has created a new muse among the Factionists. From the fashion blogs to the live streaming of catwalk shows, from the main fashion weeks to the social shopping we get diversity of opinions on different places.

Social media in the fashion industry is aiding the development of "social fashion", where expertise are applied to support art. Social media has brought fresh and innovative elements into the online shopping experience and is potentially catalyst for additional profits, giving brands and retailers an opportunity to place their products in front on thousands of potential customers in a familiar and easily reachable surroundings (Ahmad, 2015). The social networking platforms have a wider reach to the potential consumers and target market, the customizable and accommodating interface of the networking sites is introduced to them as a perfect platform to cater a larger no of audience and for expansion of business in an interactive environment (ITworld, 2020). 


\section{Content marketing as a useful strategy to build consumer engagement}

The most important strategy for creating attention to product of consumer is to provide a good content to build consumer brand engagement, it will lead to purchase intention in the future (Vivek et al., 2012). Creating quality content may influence the consumer to engage with brand which companies need to create content that keeps customers visiting website and stimulate them to engage on purchase intention (Puro, 2013). Content marketing is one of the best strategies has used for stimulate online engagement (Hollebeek, 2011). The key to create an effective engagement can be created by creating a persuasive content (Sashi, 2012). During 2-3 years, the content marketing is used widely via online.Microsoft founder Bill Gates wrote in an essay in 1996 that "content is King-it" and this means creating the appropriate content brings success (Essayhub, 2020). Content marketing is one of the best strategies has used for stimulate online engagement and has emerged simultaneously with the rise of social media (Hollebeek, 2011). Below, these concepts and strategies are explained to raise awareness on its effect on marketing.

Concepts of content marketing and consumer engagement

Content Marketing (CM) is one of advertising concept to achieve the target market. According to the content marketing institute, content marketing is a marketing technique for creating and distributing valuable, relevant and consistent content to attract and acquire a clearly defined audience with the objective of driving profitable customer action. According to Rowley (2008), content marketing can be defined as a management process where a firm can identify, analyze and satisfy customer demand to gain profit with the use of digital content distributed through electronic channels. Effective content includes interesting and relevant messages that provide personal meanings to the consumer (Fill \& Turnbull, 2016). Content marketing is creating content which has value to attract and bind consumers (Pulizzi, 2009), not only bind and be attractive but also encourage consumers to trade.

Besides attracting consumer's attention, another aim of content marketing is to create value to customers, encourage trades along with consumers spread, and also involve consumers into the company. Content marketing helps company bind consumers more with valued contents and directly relate to them. It is expected that through content marketing, companies can alter consumers' behavior by what the company wants.

Content can be present in a variety of formats including: blogs, infographics, slide decks, case studies, white papers, e-books, videos, quizzes, memes and images, etc. (Figure 1). In his study, Judy Strauss mentioned that Content marketing is a strategy involving creating and publishing content on websites and in social media. The prepared content shall be shareable, easy to understand, incentive, easily accessible, absorbing (Ahmet Andac et al., 2016).

Consumer engagement can best be described as a company's or brand's efforts to build relationships with individuals through personalized interactions on 


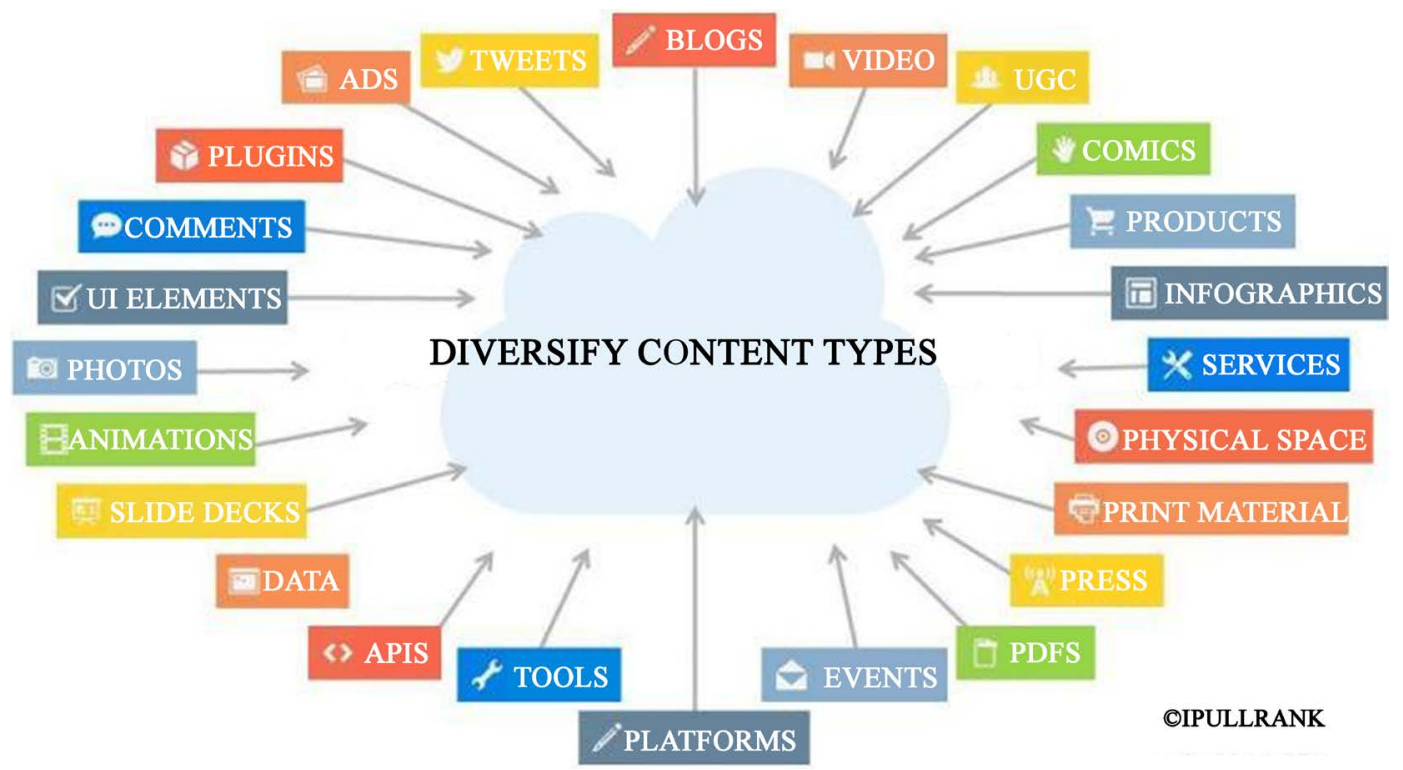

Source: https://www.easyautomatedsales.com/how-to-create-a-content-marketing-strategy/.

Figure 1. Formats of content.

multiple channels, with the goal of gaining and retaining loyal customers, Astute Solutions (2020).

The Economist Intelligence Unit defines engagement as the creation of experiences that allow companies to build deeper, more meaningful and sustainable interactions between the company and its customers or external stakeholders. Forrester Consulting's research, How engaged are your customers? defines Consumer engagement as "creating deep connections with customers that drive purchase decisions, interaction, and participation, over time".

Many other authors have defined customer engagement in several ways as follows:

Hollebeek (2011) “consumers' proactive contributions in co-creating their personalized experiences and perceived value with organizations through active, explicit, and ongoing dialogue and interactions".

Vivek et al. (2012) “The intensity of an individual's participation and connection with the organisation's offering and activities initiated by either the customer or the organization" (Figure 2).

Patterson et al. (2006) "The level of a customer's physical, cognitive and emotional presence in their relationship with a service organization".

Brodie et al. (2011) "A motivational state that occurs by virtue of interactive, co-creative customer experiences with a focal agent/object (e.g. a brand) in focal service relationships".

In the context of Saudi Arabia, fashion startups have greatly utilized content marketing and consumer engagement as useful strategies to build consumer engagement. Studies have indicated that interacting with Instagram users in order to grow the engagement rate is of growing importance. Interaction with potential customers is necessary to make a company's profile visible on Instagram and 


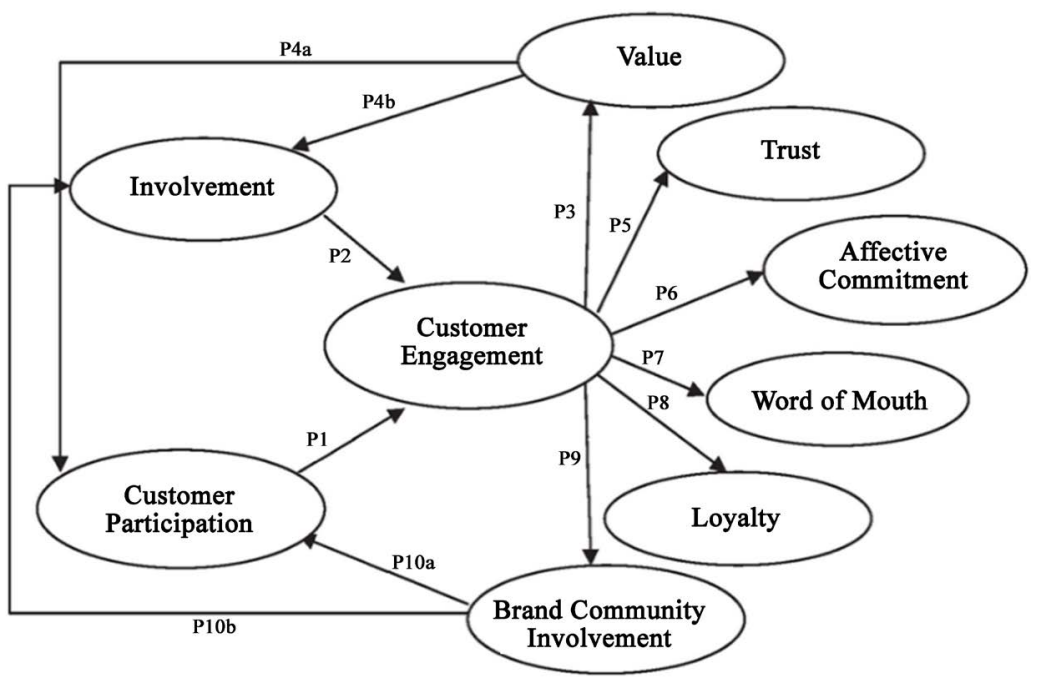

Source:

https://www.researchgate.net/figure/theoretical-model-of-Customer-engagement_fig1_279714771.

Figure 2. Theoretical model of consumer engagement by Shiri D. Vivek.

to build a strong brand. Fashion startups must recognize the rules that should be followed in order to interact with followers in the right way (Wörfel, 2019).

Consumer engagement tool that features user-generated content (UGC), explained below, is a clever way for businesses to build customer relationships.

User Generated Content; also known as, "user created content" is various types of content published by users on different online platforms (Shneiderman, Preece, \& Pirolli, 2011). UGC has been described as content created by a consortium or an individual and published through diverse online platforms (McNally et al., 2012). Leung (2009) describe UGC as any form of content that is developed by users of a service or system and published openly on an associated online platform or system. Most definitions refer to the importance of online platforms and technologies that promote the generation of such content. These platforms and technologies are types of social media, Web 2.0, collective action tools, social Web, read/write Web, consumer-generated media, virtual communities, computer-mediated communication, online communities, and socio-technical systems (Shneiderman, Preece, \& Pirolli, 2011). According to studies on the relative impact of social media on a brand's profits, UGC can have a greater impact on profits than firm-created content (Keegan \& Rowley, 2017).

The topic of the UGC can either be brand, product or service-centered or revolve around a topic/issue of interest to the consumer (Montecchi \& Nobbs, 2017). The importance of UGC is attributed to the credibility that comes from messages delivered by consumers, which are more authentic, given the higher level of trust between consumers, if compared to messages coming from the brand. UGC-based campaigns basically aim to 1) increase the number of followers; 2) support the campaign; and 3) create brand awareness, exposure and engagement (Montecchi \& Nobbs, 2017).

User generated content, sometimes displayed on Saudi fashion brands' Insta- 
gram accounts, are the type of posts that encourage Saudi consumer to buy products. As literature proves, UGC can have a greater impact on profits than professionally created content (Keegan \& Rowley, 2017). The reason for this is the consumers' ability to relate to a natural setting or UGC in comparison to a professional photoshoot which is also an incentive to purchases but can create a barrier between a brand and its consumers. Therefore, as literature explains, content can attract and retain customers by creating and curating posts (Fill \& Turnbull, 2016).

\section{Impact of influencers}

Influencers in social media are people who have made a reputation for themselves as knowledgeable and experienced on a specific topic. They contribute with regular posts on trending topic through their preferred social media platform and generate large followings of enthusiastic, engaged people who pay close attention to their views. Brands are always keen to maintain a relationship with social media influencers because they can develop trends and encourage their followers to buy products they promote.

The increasing popularity of social media platforms such as Facebook, Twitter and Instagram, have prompted fashion bloggers to start adopt a multi-channel strategy, which allows them to participate and use a variety of social media applications (Geissinger \& Laurell, 2016). This has also resulted in an increase in the number of influencers due to the ease of access to social media platforms (Geissinger \& Laurell, 2016). Influencers are trustworthy persons in the eyes of both the brand and consumers and thus, as part of their digital marketing strategies, brands have been collaborating with them to help promote products and services on social media (Bendoni, 2017).

The chart blow shows the most-followed beauty and fashion influencers on Instagram worldwide as of June 2020 (Figure 3).

\section{Saudi fashion startups and use of social media as a marketing tool}

A reason that have encouraged Saudi fashion startups to adopt the social media as a marketing tool lies in its capability to reach a great number of consumers within a short period of time. Key social medial platforms have been utilized by owners of fashion startups. An extremely large number of the Saudi population uses social media famous platforms, such as Instagram and Snapchat. The population's extensive use of those platforms has provided a new selling and marketing channel for many Saudis, especially those with low capital and a busy schedule (Al-Maghrabi \& Dennis, 2011). Therefore, social media marketing is an important element for startups as a tool to market their products. The platform most frequently used by Saudi fashion startups is Instagram, which has become famous as a marketing tool for fashion brands. Instagram is one of the most popular online platforms where users can share content with each other. The use of Instagram is no longer restricted to private users as brands are heavily using the platform to attract new customers. The concept of Instagram is to set a focus on visuals such as pictures. The idea of Instagram is to spotlight the visuals 


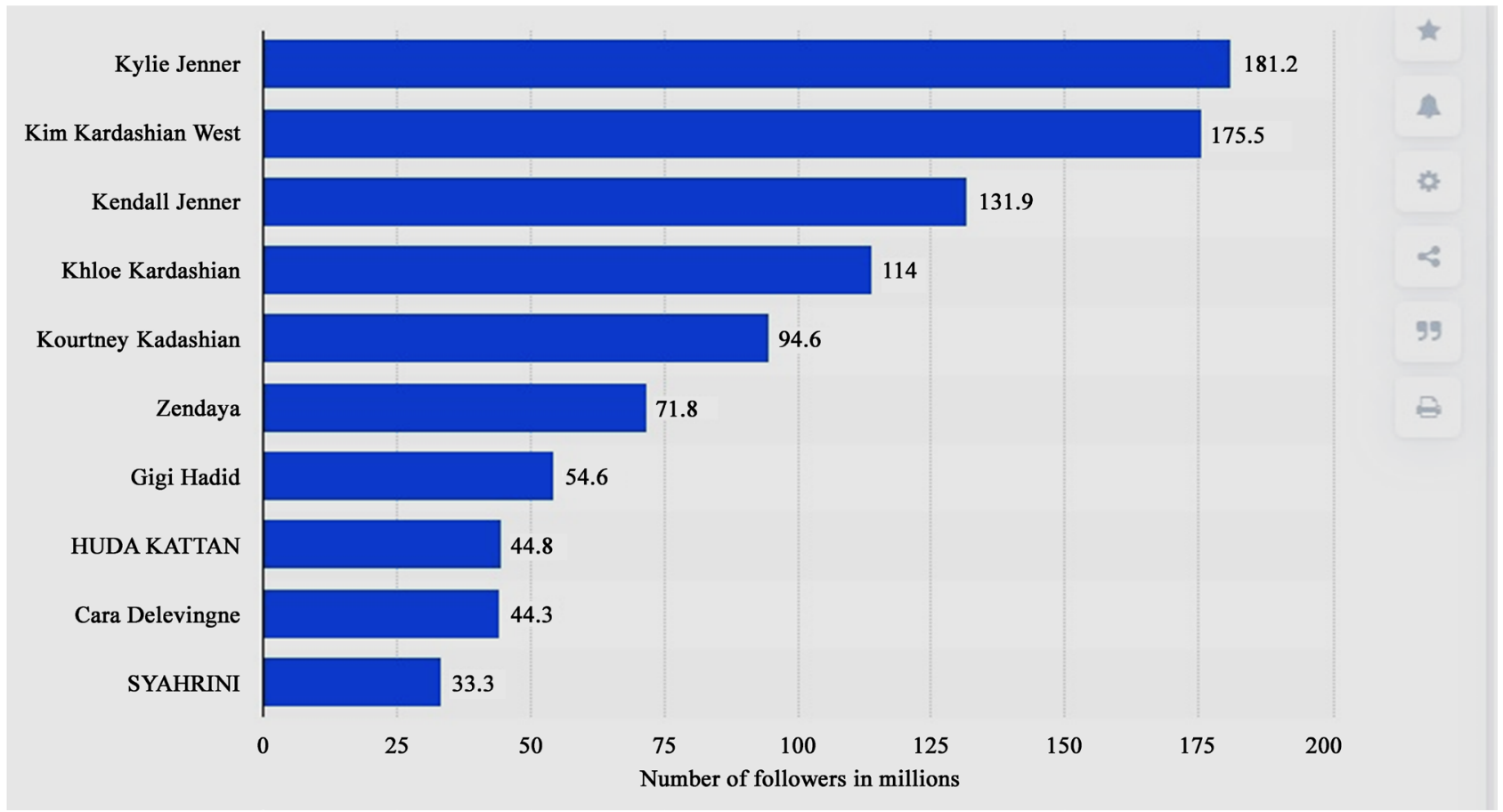

Source: https://www.statista.com/statistics/788498/most-followers-instagram-fashion-global/.

Figure 3. Most-followed beauty and fashion influencers on Instagram worldwide as of June 2020.

(Sanchez, 2018: p. 4.). In his study, Hauser has stated that there are 500 million users who visit the social media platform on a daily basis and around 800 million users are active per month (Hauser, 2018: p. 10; Sanchez, 2018: p. 6.). An essential part of the Instagram strategy is to interact with the Instagram users. Interacting includes many activities such as comments, like, or share of posts. Interacting with Instagram users is a key factor that would create and increase customer engagement. Interacting with comments and likes will make the Instagram user more valued and recognized (Wörfel, 2019).

Based on a national survey of business women in Saudi Arabia, fashion and jewelry were found to be the most common areas of female owned businesses (Danish \& Smith, 2012). The primary motivational factor for startups growth in Saudi Arabia is self-achievement. By virtue of the internet, entrepreneurs and owners of startup are able to own new selling and marketing channels that enable them to tackle traditional difficulties of consumer engagement and in return allow for self-achievement (Danish \& Smith, 2012). The global trend in the growth of female entrepreneurs can be firmly attributed to greater opportunities. Due to ease of access to social media, the past few years has witnessed a rapid increase in the number of female internet users in Saudi Arabia, mainly for business and personal reasons (Al-Maghrabi \& Dennis, 2011). According to a study by Danish and Smith, the internet has provided Saudi females with a new selling and marketing platforms to communicate with both retailers and consumers, thus ending the difficulty female entrepreneurs use to have in the past when operating or starting their own business (Danish \& Smith, 2012; Al-Maghrabi 
\& Dennis, 2011). The same study has also indicated that $94 \%$ of Saudi female entrepreneurs, who participated in the survey, pursued a business startup. This reflects the social changes that are enabling female entrepreneur empowerment as a form of self-achievement (Danish \& Smith, 2012). As per Danish and Smith, information and communication technology have played a key role in enabling Saudi women to become entrepreneurs. This is genuinely true given the significant increase in the number of female entrepreneurs in the country, who relied on the social media which facilitated the business creation process for them.

\section{Consumption trends in Saudi Arabia as a source of attraction}

The Gross Domestic Product per capita in Saudi Arabia was last recorded at 48,995.60 US dollars in 2018 compared with \$ 34,140 in 2000. The GDP per Capita, in Saudi Arabia, when adjusted by Purchasing Power Parity is equivalent to 276 percent of the world's average (tradingeconomics, 2020). As per latest statistics, consumer spending in Saudi Arabia decreased to 288,972 SAR Million in the first quarter of 2020 from 293,383 SAR Million in the fourth quarter of 2019 (tradingeconomics, 2020) (Figure 4).

Most Saudi shoppers go to shopping centers for food, clothing and electronics. According to a survey conducted by McKinsey \& Company in 2018 (McKinsey, 2018), most notably, Saudis prefer quality over quantity and are attracted by international brands. The e-commerce market represents an emerging trend in Saudi Arabia. According to an Ipsos survey conducted in 2018, its growth is even one of the largest in the world. The total value of the e-commerce market for consumer goods in the country was estimated at $\$ 6.36$ billion in 2018 , a $15 \%$ increase over the previous year. For example, $64 \%$ of Saudis now report buying a product or service online every month (Nordeatrade, 2020). The amount of consumer spending in Saudi Arabia together with the current online trading trend represents a promising market for fashion startups to sell and market their products using the various social media platforms.

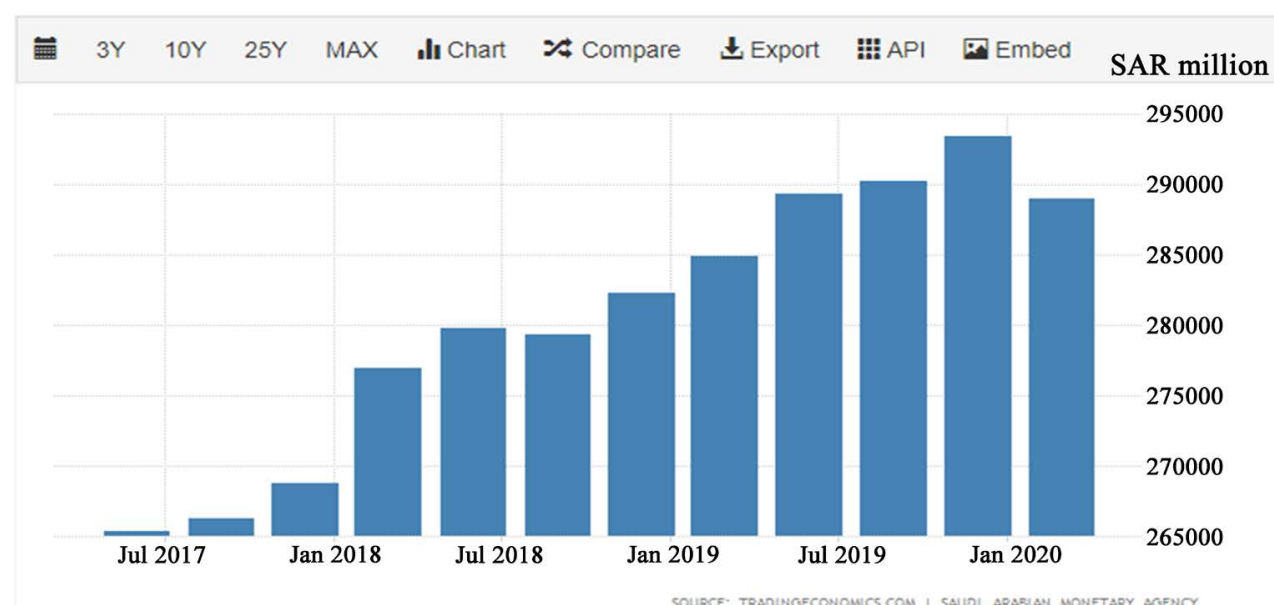

Figure 4. Consumer spending in Saudi Arabia. 


\section{Conclusion}

This paper has examined the effect of using the social media as a fashion marketing tool and how social media has provided great opportunities to marketers to raise consumers' awareness on brands. The paper has also highlighted the factors that have encouraged Saudi fashion startups to adopt the social media as a marketing tool, by virtue of its capability to reach a great number of consumers within a short period of time. The paper has highlighted the importance of Instagram being one of the most popular online platforms where fashion brands startups can market their products easily and smartly. It has also shown that fashion brands in Saudi Arabia have become heavily dependent on this platform to attract new customers, especially as users of the social media marketing platform is constantly increasing.

To raise awareness on the many concepts that are related to marketing on the social media, the researcher has shed lights on strategies such as content marketing and consumer engagement and has outlined the successful elements that ensure a successful content marketing. The searcher has also provided some insight on the role of social media influencers and how brands are keen to maintain a relationship with social media influencers because they can develop trends and encourage their followers to buy products which they promote. The researcher has also highlighted the issue of User Generated Content, and how it can have a greater impact on profits than professionally created content given its potential to attract and retain customers by creating and curating posts.

A full account about Fashion Startups in Saudi Arabia has been given and it has shown how the internet has provided Saudi entrepreneurs, specially females, with a new selling and marketing channel and offered them various platforms to communicate with both retailers and consumers, and how the use of social media has ended the difficulty female entrepreneurs used to have in the past when operating or starting their own business.

The role of social media influencers, as an important factor to promote fashion startups business activities, has been examined. The researcher has concluded that fashion brands are always keen to utilize the service of social media influencers because they can develop trends and encourage their followers to buy products they promote.

The researcher has also outlined the consumption trends in Saudi Arabia and has clarified that the rising consumer spending in Saudi Arabia, together with the customers' increasing tendency to buy fashion products through the social media, represents a promising market for fashion brands startups to sell and market their products.

Therefore, considering these factors, a fashion brand can aim to start its business through social media with a better awareness of the strategies that best fit the market.

\section{Conflicts of Interest}

The authors declare no conflicts of interest regarding the publication of this paper. 


\section{References}

Adams, P. (2011). Grouped: How Small Groups of Friends are the Key to Influence on the Social Web. Berkeley, CA: New Riders.

Ahmad, N. (2015). The Impact of Social Media on Fashion Industry: Empirical Investigation from Karachiites.

Al-Maghrabi, T., \& Dennis, C. (2011). "What Drives Consumers" Continuance Intention to e-Shopping? Conceptual Framework and Managerial Implications in the Case of Saudi Arabia. International Journal of Retail \& Distribution Management, 39, 899-926. https://doi.org/10.1108/09590551111183308

Andac, A., Akbyk, F., \& Karkar, A. (2017). Customer Satisfaction Factor in Digital Content Marketing: Isparta Province as an Example. International Journal of Social Science Studies, 4, 124-135. http://ijsss.redfame.com https://doi.org/10.11114/ijsss.v4i5.1471

Astute Solutions (2020). What Is Consumer Engagement Really All about? https://www.astutesolutions.com/blog/articles/what-is-consumer-engagement

Bendoni, W. K. (2017). Social Media for Fashion Marketing Storytelling in a Digital World. London: Bloomsbury Visual Arts.

Berthon, P. R., Pitt, L. F., Plangger, K., \& Shapiro, D. (2012). Marketing Meets Web 2.0, Social Media, and Creative Consumers: Implications for International Marketing Strategy. Business Horizons, 55, 261-271. https://doi.org/10.1016/j.bushor.2012.01.007

Brodie, R., Hollebeek, L. D., Ilic, A., \& Juric, B. (2011). Customer Engagement: Conceptual Domain, Fundamental Propositions \& Implications for Research in Service Marketing (Lead Article; with Commentaries). Journal of Service Research, 14, 252. https://doi.org/10.1177/1094670511411703

Buhalis, D., \& Foerste, M. (2015). SoCoMo Marketing for Travel and Tourism: Empowering Cocreation of Value. Journal of Destination Marketing \& Management, 4, 151-161. https://doi.org/10.1016/j.jdmm.2015.04.001

Chaffey, D., \& Ellis-Chadwich, F. (2016). Digital Marketing Strategy, Implementation and Practice. Harlow: Pearson Education Limited.

Chen, Y., Fay, S., \& Wang, Q. (2011). The Role of Marketing in Social Media: How Online Consumer Reviews Evolve. Journal of Interactive Marketing, 25, 85-94.

https://contentmarketinginstitute.com/what-is-content-marketing https://doi.org/10.1016/j.intmar.2011.01.003

Clement, J. (2019). Instagram Monthly Active Users.

Clement, J. (2020). Facebook MAU Worldwide 2020. https://www.statista.com/statistics/264810/number-of-monthly-active-facebook-usersworldwide

Danish, A., \& Smith, H. (2012). Female Entrepreneurship in Saudi Arabia: Opportunities and Challenges. International Journal of Gender and Entrepreneurship, 4, 216-235. https://doi.org/10.1108/17566261211264136

eMarketer (2018). Social Network Users and Penetration in Worldwide. https://tinyurl.com/ycr2d3v9

Essamri, A., McKechnie, S., \& Winklhofer, H. (2019). Co-Creating Corporate Brand Identity with Online Brand Communities: A Managerial Perspective. Journal of Business Research, 96, 366-375. https://doi.org/10.1016/j.jbusres.2018.07.015

Essayhub (2020). “Content Is King”-Essay by Bill Gates 1996. https://essayhub.net/essays/content-is-king-essay-by-bill-gates-1996 
Facebook (2019). Company Info. https://tinyurl.com/n544jrt

Fill, C., \& Turnbull, S. (2016). Marketing Communications: Discovery, Creation and Conversations (7th ed.). Harlow: Pearson Education Limited.

Gallaugher, J., \& Ransbotham, S. (2010). Social Media and Customer Dialog Management at Starbucks. MIS Quarterly Executive, 9, Article 3.

Geissinger, A., \& Laurell, C. (2016). User Engagement in Social Media-An Explorative Study of Swedish Fashion Brands. Journal of Fashion Marketing and Management, 20, 177-190. https://doi.org/10.1108/JFMM-02-2015-0010

Gielens, K., \& Steenkamp, J.-B. E. M. (2019) Branding in the Era of Digital (Dis)intermediation. International Journal of Research in Marketing, 36, 367-384.

https://doi.org/10.1016/j.ijresmar.2019.01.005

Hauser, J. (2018). Instagram-The New Facebook, Boosting Your Business with Instagram Marketing. Unterhaching: Eugen Grinschuk.

Hill, R. P., \& Moran, N. (2011). Social Marketing Meets Interactive Media: Lessons for the Advertising Community. International Journal of Marketing, 30, 815-838. https://doi.org/10.2501/IJA-30-5-815-838

Hollebeek, L. (2011). Demystifying Customer Brand Engagement: Exploring the Loyalty Nexus. Journal of Marketing Management, 27, 785-807. https://doi.org/10.1080/0267257X.2010.500132

ITworld (2020). Social Networks Change the Online Retail Game.

Keegan, B., \& Rowley, J. (2017). Evaluation and Decision-Making in Social Media Marketing. Management Decision, 55, 15-31. https://doi.org/10.1108/MD-10-2015-0450

Leung, L. (2009). User-Generated Content on the Internet: An Examination of Gratifications, Civic Engagement and Psychological Empowerment. New Media \& Society, 11, 1327-1347. https://doi.org/10.1177/1461444809341264

McKinsey (2018). https://www.mckinsey.com/featured-insights/artificial-intelligence/global-ai-survey-aiproves-its-worth-but-few-scale-impact

McNally, M. B., Trosow, S. E., Wong, L., Whippey, C., Burkell, J., \& McKenzie, P. J. (2012). User-Generated Online Content 2: Policy Implications. First Monday, 17. https://doi.org/10.5210/fm.v17i6.3913

Montecchi, M., \& Nobbs, K. (2017). Let It Go: Consumer Empowerment and User-Generated Content-An Exploratory Study of Contemporary Fashion Marketing Practices in the Digital Age. In A. Vecchi (Eds.), Advanced Fashion Technology and Operations Management (pp. 294-317, Chapter 13). Hershey, PA: IGI Global. https://doi.org/10.4018/978-1-5225-1865-5.ch013

Nordeatrade (2020). https://www.nordeatrade.com/en/explore-new-market/saudi-arabia/marketing

Patterson, P., Yu, T., \& de Ruyter, K. (2006). Understanding Customer Engagement in Services.

Pitt, L., Berthon, P., Watson, R., \& Zinkhan, G. (2002). The Internet and the Birth of Real Consumer Power. Business Horizons, 45, 7-14. https://doi.org/10.1016/S0007-6813(02)00220-3

Posner, H. (2015). Marketing Fashion Strategy, Branding, and Promotion (2nd ed.). London: Laurence King Publishing Ltd.

Pulizzi, J., \& Barrett, N. (2009). Get Content, Get Customers: Turn Prospects into Buyers with Content Marketing. New York: McGraw-Hill. 
Puro, P. (2013). Content Marketing and the Significance of Corporate Branding. Master Thesis, Lappeenranta: Lappeenranta University of Technology.

Rowley, J. (2008). Understanding Digital Content Marketing. Journal of Marketing Management, 24, 517-540. https://doi.org/10.1362/026725708X325977

Sanchez, J. (2018). Instagram Marketing-Comprehensive Beginners Guide to Learn Instagram Marketing from $A$ to $Z$.

Sashi, C. M. (2012). Customer Engagement, Buyer-Seller Relationships, and Social Media. Management Decision, 50, 253-272. https://doi.org/10.1108/00251741211203551

Shneiderman, B., Preece, J., \& Pirolli, P. (2011). Realizing the Value of Social Media Requires Innovative Computing Research. Communications of the ACM, 54, 34-37. https://doi.org/10.1145/1995376.1995389

tradingeconomics (2020). https://tradingeconomics.com/saudi-arabia/gdp-per-capita-ppp

Vivek, S. D., Beatty, S. E., \& Morgan, R. M. (2012). Customer Engagement: Exploring Customer Relationships beyond Purchase. Journal of Marketing Theory and Practice, 20, 122-146. https://doi.org/10.2753/MTP1069-6679200201

Wörfel, S. (2019). Brand-Awareness through Marketing on Instagram-An Instagram Marketing Strategy for ONIMOS Clothing. 